\title{
Kinerja sistem kontrol level air drum boiler pada pembangkit listrik tenaga uap kapasitas $625 \mathrm{MW}$
}

\author{
${ }^{1}$ Agus Yogianto *), 2 Pirnando Tarigan \\ 1,2, STT PLN \\ (aayogi08@yahoo.com, *)
}

\begin{abstract}
Abstrak
Kinerja dari pembangkit listrik tenaga uap, salah satunya tergantung pada kinerja sistem kontrol yang terdapat pada sistem boiler. Salah satu sistem kontrol pada boiler yang termasuk utama adalah sistem kontrol level air drum boiler. Pada sistem kontrol level air, pengukuran level air drum tanpa kompensasi, belum dapat menghasilkan pengukuran yang optimal bagi sistem kontrol level air drum. Kondisi dua fasa, air dan uap memberikan pengaruh kepada densitas air menjadi tidak linier terhadap perubahan tekanan hidrostatik. Oleh sebab itu satu variabel lain yaitu tekanan uap drum juga digunakan untuk memberikan kompensasi karena terdapat suatu hubungan antara densitas air dan densitas uap terhadap tekanan uap. Kinerja sistem kontrol level diukur dengan dua parameter yaitu kesalahan dan stabilitas. Dari segi kesalahan terhadap target level air drum pada unit pembangkit ini, harga kesalahan maksimum termasuk kurang baik, sedangkan dari segi stabilitas sistem kontrol termasuk baik.
\end{abstract}

Kata Kunci: Pengukuran level, sistem kontrol level,drum boiler, kinerja sistem kontrol, kesalahan, standard deviasi, stabilitas

\section{Pendahuluan}

Pengukuran level air dengan densitas atau gravitas yang tetap cukup dengan menerapkan prinsip tekanan hidrostatis. Pengukuran level diperoleh dari kesebandingan antara level dengan tekanan hidrostatik, atau perbedaan level diperoleh dengan perbedaan tekanan hidrostatik.

Pengukuran level air pada operasi boiler, tidak memadai bila diukur hanya dengan perbedaan tekanan serta satu harga densitas saja yaitu densitas air, karena didapat hasil pengukuran yang kurang dari nilai sebenarnya. Kondisi ini terjadi, karena terdapat dua jenis fluida yaitu air dan uap dalam drum yang masing-masing mempunyai densitas berbeda serta densitas tersebut tergantung kepada tekanan dalam drum. Pemberian relasi perubahan tekanan drum terhadap densitas air dan uap dapat memberikan koreksi terhadap pengukuran level air drum.
Sistem kontrol level air drum di unit pembangkit listrik tenaga uap merupakan salah satu sistem kontrol utama di boiler yang menentukan kinerja boiler unit pembangkit. Sementara itu kinerja unit pembangkit ditentukan oleh kinerja boiler sebagai peralatan utama unit pembangkit. Oleh sebab itu, kinerja sistem kontrol level air perlu dipastikan dengan kriteria tertentu berada dalam kondisi yang memenuhi kebutuhan unit.

Kinerja sistem kontrol unit pembangkit terutama pada pembangkit listrik tenaga uap biasanya dibuat optimal dalam range operasi pada beban yang maksimal. Oleh sebab itu pada pengambilan data dilakukan pada beban yang relatif tinggi,

\section{Sistem kontrol level}

Pada sistem kontrol level air, sebagai dasar untuk mendapatkan besaran level dilakukan dengan pengukuran level air drum yang diperoleh dengan metoda pengukuran beda tekanan.

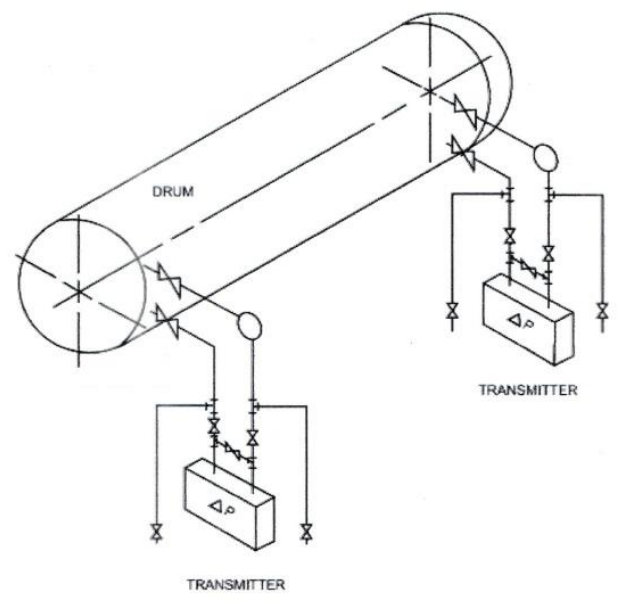

Gambar.1. Pengukuran level air di drum boiler 
Perbedaan tekanan diukur dengan instrumen differential pressure transmitter (DPT) yang dipasang seperti pada gambar.1. Tap tekanan dari transmitter, salah satu berfungsi sebagai line acuan dan line satu lagi berfungsi sebagai line pengukuran.

Perbedaan tekanan antara sisi tekanan tinggi dan sisi tekanan rendah dari differential pressure transmitter adalah

$$
\Delta p=(\mathrm{H}-\mathrm{h}) \mathrm{Gs}+\mathrm{h} \mathrm{Gwu}-\mathrm{H} \cdot \mathrm{Ga}
$$

Bila $K_{1}=H . G a$ dan $K_{2}=G a$

Nilai level air dengan koreksi dari tekanan uap di drum adalah 5]:

$$
h=\left[\Delta p-\left(K_{1} / K_{2}\right) G s+K_{1}\right] /(G w u-G s)
$$

dengan :

$\mathrm{Pd}=$ tekanan uap dalam drum

$\mathrm{H}=$ tinggi line acuan dari tap dasar

$\mathrm{h}=$ tinggi permukaan air di atas tap dasar

hv = jarak dari DPT ke kaki acuan atau tap dasar

Gs = gravitas spesifik uap pada tekanan Pd

$\mathrm{Gwu}=$ gravitas spesifik air di drum tekanan $\mathrm{Pd}$

$\mathrm{Ga}=$ gravitas spesifik air pada line acuan

Pada operasi boiler tersebut Gwu dan Gs sebagai fungsi dari Pd

Pada unit pembangkit ini ada tiga lokasi tap untuk pengukuran beda tekanan. Pengukuran level diperoleh dengan mengambil nilai median tiap pengukuran level yang didapat dari masing-masing tiap lokasi pengukuran.

Nilai level yang diperoleh dan digunakan untuk monitoring dan kontrol adalah dari nilai rata-rata tiga nilai level yang diperoleh. Selanjutnya nilai level air tersebut digunakan sebagai nilai yang ditampilkan pada display atau sistem pemantauan dan sebagai salah satu masukan pada sistem kontrol level.

Sistem kontrol level di unit pembangkit listrik tenaga uap pada kondisi operasi berbeban memakai beberapa masukan untuk mendapatkan perintah kontrol, yang dikenal sebagai sistem dengan tiga elemen. Dalam hal ini ada elemen level air, aliran air pengisi dan aliran uap.

Dinamika level air dalam drum sangat besar, dengan dua fasa air dan uap yang bervariasi sesuai dengan tekanan di dalam drum. Sistem kontrol level dengan hanya mengandalkan satu masukan kontrol dari level air saja akan menghasilkan berbagai ketidaksinkronan pada performa sistem kontrol level.
Ketika beban naik, maka aliran uap bertambah, sedangkan pada permukaan air terbentuk gelembung yang dideteksi sebagai kenaikan level (swell) seperti pada gambar.2, sehingga disaat awal perubahan kenaikan beban, aliran air pengisi berkurang yang berakibat level air turun sedangkan yang diperlukan adalah penambahan air pengisi untuk menaikkan level air.

Sebaliknya ketika beban turun, aliran uap berkurang dan tekanan dalam drum bertambah, yang berakibat permukaan air tertekan turun (shrink) seperti pada gambar.2, sehingga pada saat awal deteksi level air memerintahkan sistem kontrol untuk penambahan air pengisi yang berlawanan dengan kondisi yang diharapkan yaitu pengurangan air pengisi.

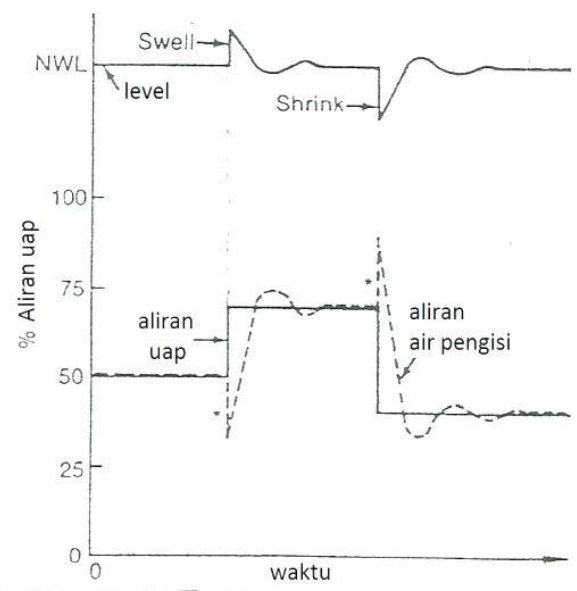

Gambar. 2 Kondisi swell dan shrink di drum boiler

Oleh sebab itu, pada operasi berbeban dengan hanya menggunakan satu elemen input kontrol yaitu level air di drum saja sudah tidak memadai lagi.

Perubahan beban langsung mempengaruhi perubahan aliran uap yang diperlukan turbin untuk menghasilkan daya. Oleh sebab itu aliran uap diperlukan sebagai input umpan maju terhadap input level air. Sementara itu jumlah penambahan air pengisi diperlukan dengan membandingkannya terhadap aliran uap, sehingga output kontrol dari level dan aliran uap menjadi setpoint bagi aliran air pengisi.

Diagram fungsional sistem kontrol level air dengan tiga elemen dapat dilihat pada gambar.3

Kinerja sistem kontrol level air drum tiga elemen dapat diresume sebagai berikut : 
Kenaikan beban : adanya kenaikan beban yang berakibat kenaikan aliran uap akan menurunkan tekanan dalam drum dan kenaikan level air sesaat. Deteksi terhadap kenaikan aliran uap menghasilkan aksi ke perintah kontrol untuk menambah aliran air pengisi, sementara level air yang naik menghendaki aliran air pengisi berkurang.

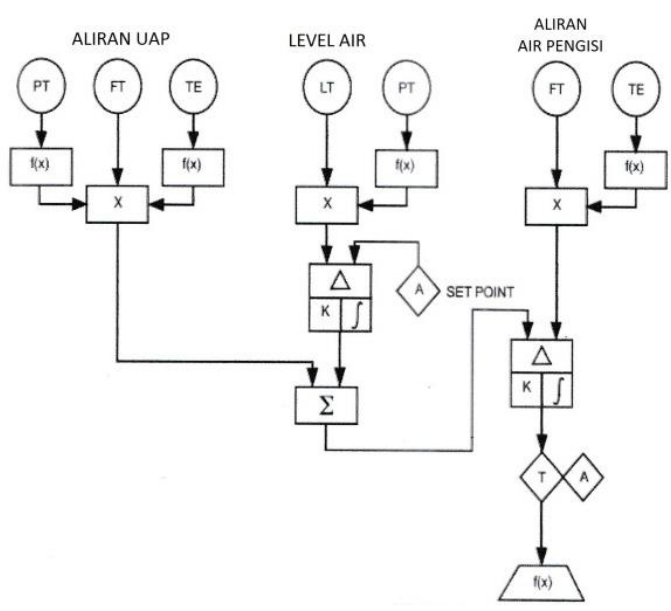

Gambar.3 Diagram fungsional sistem kontrol level air drum

Aksi total yang dihasilkan adalah perubahan kenaikan yang sedikit pada aliran air pengisi. Setelah tekanan uap di drum stabil, maka selanjutnya efek dari kenaikan aliran uap adalah menambah aliran air pengisi untuk mempertahankan level air drum pada setpointnya.

Penurunan beban : Pada kondisi beban turun, maka tekanan drum naik sehingga level air turun pada awalnya. Kondisi level air turun direspon dengan kecenderungan menambah aliran air pengsii, tetapi hal ini dilawan oleh adanya penurunan aliran uap yang menghendaki pengurangan aliran air pengisi. Hasil dari aksi kontrol ini adalah hanya terjadi perubahan sedikit pada aliran air pengisi atau bahkan tidak terjadi perubahan aliran sama sekali. Setelah tekanan dalam drum stabil, pengurangan aliran uap diikuti dengan pengurangan aliran air pengisi.

Pada kondisi unit pembangkit berbeban sekitar 600 MW dilakukan pengamatan terhadap sistem kontrol level air drum dengan hasil sebagai mana pada kurva berikut :

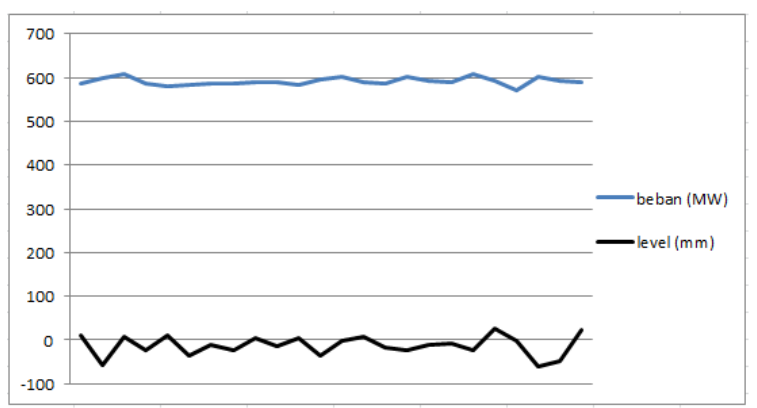

Gambar.4 Dinamika beban dan level air drum

Beban yang bervariasi akan menghasilkan variasi pula pada level air drum. Pada kondisi kenaikan beban diawali dengan penurunan level air, sementara pada kondisi penurunan beban diawali dengan kenaikan level air drum.

Penilaian terhadap kinerja sistem kontrol dilakukan dengan mengambil dua parameter yaitu kesalahan atau error dari variabel level dan standard deviasi nilai level air dalam periode pengamatan.

Kesalahan atau error didefinisikan sebagai selisih antara variabel yang dikontrol dengan nilai set point.

Dalam persentase kesalahan ditentukan sebagai :

$$
\text { Kesalahan }=\frac{\text { Nilai level }- \text { Setpoint level }}{\text { Range level }} \times 100 \%
$$

Pada parameter kesalahan, sistem kontrol dievaluasi dengan kriteria kesalahan sebagai berikut :

Kesalahan $<=2 \%$ : baik

Kesalahan antara $2 \%$ - 5\% : cukup baik

Kesalahan $>5 \%$ : kurang baik

Dalam hal parameter kedua yaitu standard deviasi (SD), parameter ini digunakan untuk mengukur stabilitas dari sistem kontrol, yang kriteria pembobotannya, 2]

$$
\begin{aligned}
& \mathrm{SD}=<3 \% \text {, baik } \\
& \mathrm{SD}>3 \% \text {, kurang baik }
\end{aligned}
$$

Data pengamatan diambil setiap menit yaitu beban unit pembangkit, besaran level, besaran aliran uap dan aliran air pengisi. Berikut ini tabel ringkasan dari pengamatan beban dan level air yang ditampilkan setiap waktu 20 menit. 
Seminar Nasional Instrumentasi, Kontrol dan Otomasi (SNIKO) 2018 Bandung, Indonesia, 10-11 Desember 2018

Tabel 1 Ringkasan pengamatan beban dan level

\begin{tabular}{|c|c|c|}
\hline No & $\begin{array}{c}\text { Beban } \\
(\mathrm{MW})\end{array}$ & $\begin{array}{c}\text { Level air } \\
(\mathrm{mm})\end{array}$ \\
\hline 1 & 585 & 9,0 \\
\hline 2 & 609 & 7.0 \\
\hline 3 & 581 & 11,7 \\
\hline 4 & 587 & $-9,7$ \\
\hline 5 & 588 & 5,5 \\
\hline 6 & 583 & 3,3 \\
\hline 7 & 602 & $-1,5$ \\
\hline 8 & 588 & $-18,5$ \\
\hline 9 & 594 & $-10,3$ \\
\hline 10 & 609 & $-22,7$ \\
\hline 11 & 571 & $-1,0$ \\
\hline
\end{tabular}

Dari sekumpulan data pengamatan level air tersebut, maka dapat dihitung parameter kesalahan level serta standard deviasi dari level yang dihitung dalam persentase. Sebagai nilai base untuk menghitung persentase diambil range pengukuran level antara - $400 \mathrm{~mm}$ sampai dengan $+400 \mathrm{~mm}$.

Persentase kesalahan level air drum selama periode waktu tertentu diberikan pada gambar.5 berikut ini

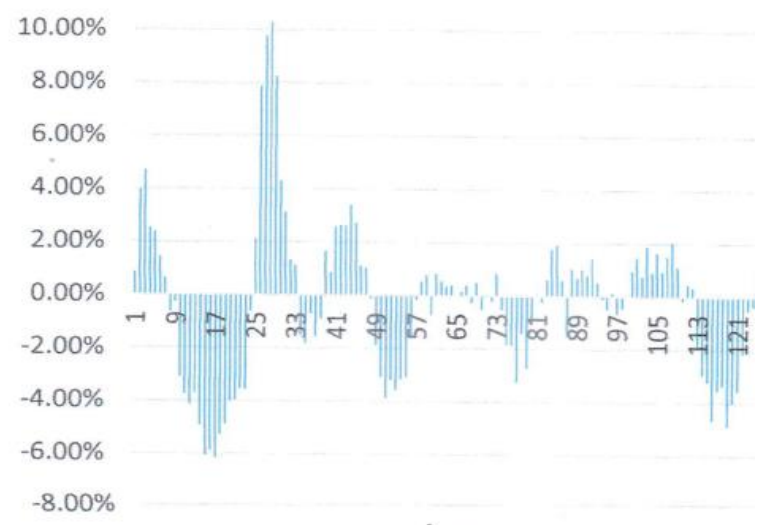

Gambar.5 Dinamika kesalahan level air drum

Dari data pengamatan level air, diperoleh nilai kesalahan level air yang tertinggi adalah: 10,26 \% pada $+72,1 \mathrm{~mm}$

Dari data yang didapat, nilai standard deviasi level air yang diperoleh dari variansi yaitu sebesar $2,96 \%$.
Batasan operasi untuk nilai level air drum adalah seperti pada tabel 2.

Tabel 2 Batasan operasi nilai level air drum

\begin{tabular}{|l|l|l|}
\hline \multicolumn{1}{|c|}{ Parameter } & $\begin{array}{c}\text { Level } \\
(\mathrm{mm})\end{array}$ & \multicolumn{1}{|c|}{ Keterangan } \\
\hline Range atas & +400 & Level maksimum \\
\hline Range rendah & -400 & Level minimum \\
\hline Set level tinggi & 120 & Alarm \\
\hline Set level rendah & -170 & Alarm \\
\hline Set level tinggi & 370 & Trip \\
\hline Set level rendah & -300 & Trip \\
\hline Set Point Level & -10 & Operasi \\
\hline
\end{tabular}

Selama pengamatan, nilai level maksimum $+72,1$ $\mathrm{mm}$ dan minimum - 61,3 $\mathrm{mm}$ yang berarti masih jauh dari batasan level tinggi atau rendah yang berakibat ada indikasi alarm atau bahkan batasan trip boiler. Kondisi dinamika level yang demikian menunjukkan sistem kontrol level air mampu menjaga variabel yang dikontrol dalam batas operasi yang aman.

Berdasarkan parameter nilai kesalahan level, maka kinerja sistem kontrol level dalam kondisi bervariasi mulai dari kondisi baik, cukup baik sampai dengan kurang baik.

Berdasarkan standard deviasi, maka dapat dikatakan performa sistem kontrol level mempunyai stabilitas yang baik.

Terkait dengan nilai kesalahan yang mempunyai variasi, hal ini karena dinamika perubahan dari air serta uap dalam kapasitas yang relatif besar mempengaruhi waktu respon sistem kontrol yang diawali dengan mulai dari proses pengukuran level yang kondisinya juga dinamis.

\section{Kesimpulan}

Dari hasil pengamatan dan pembahasan terkait kinerja sistem kontrol level air drum boiler, maka disimpulkan sebagai berikut :

1. Dinamika level air drum pada boiler unit pembangkit kapasitas $625 \mathrm{MW}$ relatif besar.

2. Kesalahan atau error yang bervariasi membuat kinerja sistem kontrol level drum berada pada kondisi kategori baik, cukup baik atau kurang baik.

3. Stabilitas sistem kontrol level drum berdasarkan standard deviasi level 
selama periode pengamatan dapat diklasifikasikan sebagai kategori baik.

\section{Daftar Pustaka}

[1] David Lindsley, Power plant control and instrumentation. The control of boilers and HRSG systems, The Institute of Electrical Engineers, London, 2000

[2] George Buckbee PE,"Guidelines for evaluating control system performance",
[3] G F (Jerry) Gilman, Boiler Control Systems Engineering, Second edition, ISA, 2010

[4] Ogata, K, Modern control engineering, Prentice Hall Int, second edition, 1990

[5] Paul S Baur, "Combustion Control and Burner Management", Power, September, 1982, S.12-14.

[6] "Boiler Instrumentation and Auxilliary Equipments", Power, June, 1988, 
Seminar Nasional Instrumentasi, Kontrol dan Otomasi (SNIKO) 2018

Bandung, Indonesia, 10-11 Desember 2018 